\title{
Analysis and suggestions on restrictive factors of green credit
}

\author{
implementation \\ Qian Cao ${ }^{*}$, Wenxin Tan \\ Shandong University of Finance and Economics, Jinan Shandong \\ *Corresponding author: Qian Cao,29890556@qq.com
}

\begin{abstract}
The cost of resources and environment for economic growth in China is too large. From the perspective of property rights, this is because the cost of enterprises using environmental resources is often highly externalized. The "market failure" caused by this externality is the root cause of environmental degradation. This paper analyzes the implementation environment and practical significance of green credit from the perspective of economics, and reviews the relevant research literature, discusses the preliminary implementation of green credit in financing institution and the existing problems and risks of green credit from perspectives of tripartite duty, environmental assessment fairness and timeliness, institutional profit. Then the paper puts forward the policy proposal to further and better implement the green credit, try to use the third party supervision to construct the interest coordination mechanism, and use law, finance and taxation to promote the social responsibility of the main body and establish intellectual support platform and environmental data sharing information. Use these means to provide advisory reference for China to effectively carry out green credit, strengthen environmental protection and management, and implement ecological civilization strategy.
\end{abstract}

Keywords: environmental protection, green credit, credit risk, policy recommendations

\section{Introduction}

The 18th CPC National Congress proposed to strengthen the construction of ecological civilization, improve the compensated use of resources and ecological compensation mechanism, speed up pollution control and strengthen environmental protection through the supply side reform. To this end, Ministry of Environmental Protection, the People's Bank of China and China Banking Regulatory Commission jointly developed advice on providing financial support for environmental protection investment, requiring implementation of green 
credit. Green credit aims to enhance and optimize the industrial structure through investment and financing. It is a special financial policy product for the purpose of green development. The loan strictly controls the loan amount of "three high" (high pollution, high energy consumption and high emission) projects. It improves the lending rates of "three high" project, and gives lower lending rates to energy-saving environmental protection industry and other green industry.

Research shows that economic development depends mainly on factor input of environmental resources as productivity, but to achieve sustainable development, society must govern and repair environmental resources. According to a study conducted by the World Bank for environmental protection investment in 1997, it was found that if environmental investment accounted for about 3.1\% of GDP, the economic rate of return brought by pollution reduction due to environmental investment was $114 \%$, and the most representative was water pollution governance, its rate of return was $236 \%$, and the rate of return on air pollution governance was just behind it, which was about $117 \%$.

Compared with the developed countries, China's cost of resources and environment for its economic growth is too large. In other words, China's environmental problems are very serious. From a certain sense, our development is at the cost of sacrificing the environment. It is the typical "treatment after pollution". Basically speaking, the environmental problems are mainly brought about by the extensive economic growth. About the data of China's environmental pollution losses in 1995, the World Bank believed in 1995 that it accounted for 9.7\% of the GDP at the same period too the largest, and 2.1\% too the smallest (1992, United States). In 2004, it accounted for 3.05\% of GDP over the same period. Foreign studies suggest that China has contributed a limited environment to the world. In July 2007, in order to assist the construction of national ecological civilization, the State Environmental Protection Administration, People's Bank of China and China Banking Regulatory Commission jointly issued the "Opinions on the Implementation of Environmental Protection Policies and Regulations to Prevent Credit Risk (UNCED [2007] No. 108 (Hereinafter referred to as "opinions"), which puts forward new requirements for investment and financing from aspects such as adjusting fiscal revenue and foreign trade institutions, and speeding up pollution control, and encourage the implementation of green credit. 


\section{Literature review of green credit in China}

Foreign scholars start the research on the green credit very early. Aizawa ${ }^{1}$ summed up the three factors that affect the effectiveness of green credit implementation: efficient collection and delivery of environmental data, financial regulation and technical guidance, and incentives for the banking sector. Bing ${ }^{2}$ thinks that China's green credit policy lacks detailed implementation details and environmental information, and has a fatal blow to high pollution and high energy consumption industry. Conley ${ }^{3}$ measured the actual effect of the equatorial criteria by questionnaires, and the results showed that only some people agreed that the equatorial criteria was indeed conducive to environmental protection. Thomas ${ }^{4}$ accurately calculates the environmental hazard coefficient of the loan project after considering the external environmental costs, making it easier for financial institutions to understand the potential risks of the project. Elielle ${ }^{5}$ found that the value matrix, value collection and green compensation is the important factors affecting the green credit tool based on the method of value matrix.

Domestic scholars start the study of green credit very late, mainly concentrated in the following three aspects. First, investigate whether the green credit really promote environmental protection and development of commercial banks from the perspective of performance evaluation. Zheng Chong ${ }^{6}$ found that the implementation of green credit, not only achieves the transfer of bank risk and business increase, but also provides financial support for achieving the sustainable development of economy and the protection of environment. Hu Naiwu, Cao Dawei ${ }^{7}$ showed that the emergence of green credit stimulates the improvement of environmental risk management level of commercial banks from the perspective of green credit and environmental risk management. Cao Hongjun, Chen Yimeng $(2010)^{8}$ studied the behavior of banks and enterprises under the theory of game theory, and found that the main body of the transaction tends to collude with each other in the absence of constraints, it's essential to improve the supervision and restraint mechanism of green credit. The second is to draw lessons from the experience of green credit in western countries and summarize the successful experience of China's commercial banks, and then design China's green credit path, or fully analyze the necessity, implementation and existing problems of green credit in China. Zhang Luyang $(2016)^{9}$ took low-carbon credit as a representative of green credit. Chen Liming, Guo Lihua and Zhang Weiwei (2016) ${ }^{10}$ used the ecological mechanism to calculate the maximum green economic development value. Jiang Xianling, Xu Helong (2016) ${ }^{11}$ referred to the successful experience of implementing green 
credit at home and abroad, and built a green credit efficient operation mechanism of commercial banks, government and enterprises. Zeng Yu, Chen Dan (2016) ${ }^{12}$ explored the path of green credit supporting urbanization development from the perspective of supply side reform. Third is to use relevant data to test the implementation effect of green credit empirically. Cai Haijing (2016) ${ }^{13}$ selected the green credit data in paper, mining and power industries in July 2007. Liu Jingyu, Xia Yan, Lin Shiming et al. (2015) ${ }^{14}$ used the CGE model of China's 2007 listed companies' SAM table structure and the financial system factor, and got the conclusion that the green credit can effectively reduce the output of polluting industries in the short and medium term. Hu Zhenyun, Chen Chen, Zhang Wei ${ }^{15}$ constructed the differential game model of continuous time, and took the accumulation of pollution in the river as an environmental variable to confirm that the government incentives and green credit policies can improve environmental pollution.

The existing research results show that most of the researches are confined to the simple combing of domestic and international green credit system development dilemma and model. The research method is mainly qualitative analysis, very single. The research conclusions are lack of empirical evidence support. As the the effect of green credit in the short term is significant, the green credit borrowing time has become one of the important issues. This paper intends to construct the green credit incentive system from two aspects: institutional innovation and product innovation.

The green credit policy of China's financial institutions has just started. From the perspective of new things, the concrete operation will continue to face many problems. At the same time, it involves multi-sectoral coordination and cooperation. Therefore, we need to pay attention to risks and problems of green credit policy.

\section{Challenges for the development of green credit for commercial banks}

The status and responsibility of financial sector, enterprise and government is not clear. In the current green credit work, it urgently requires to clearly defining the status and responsibility of the above three sides in cooperation ${ }^{16}$. For example, who is responsible for the environmental impact assessment of enterprises, local environmental protection departments, enterprises themselves or financial institutions? How to timely and accurately reflect the environmental impact assessment of relevant enterprises to financial sector, how the three sides assign the research responsibility of relevant stakeholders (such as the research of community environment)? If not conducting research, it is possible for financial institutions 
and enterprises to suffer heavy losses because the objection of community residents suspends the loan of important projects which have passed the environmental impact assessment. This is very important. The environmental protection department is not obliged to conduct research on the relevant stakeholders in the community; neither does the financial sector have this obligation. Therefore, this is likely to be the responsibility of enterprises, but it can't guarantee the authenticity of the results from the perspective the enterprise.

Unify standards, and have poor channel to publish authoritative and impartial EIA report to society in time. Whether the environmental protection department's enterprise environmental impact assessment results are authoritative? Whether the financial sector can conduct environmental protection "one-vote veto system" only according to EIA results of environmental protection departments? Will it be able to eradicate the environmental risk of credit if make loans according to the results of the EIA? The current assessment policy of environmental protection comes from many departments, and the actual operation of financial institutions is difficult to have a unified standard ${ }^{17}$. This requires environmental protection departments to standardize the various environmental titles given to enterprises. Environmental protection departments and the financial sector work together to determine a unified specification to address the authoritative and unique issues of environmental protection departments' EIA results.

Establish information platform, and timely release the relevant information of environmental protection and ecological civilization construction to the society, which is a long way to go ${ }^{18}$. First is that it can't guarantee the timely and effective information. The timeliness of the updating of EIA results. If the EIA results can't be updated in time, it will delay the financing of enterprises, so that enterprises lose the favorable investment or development opportunities, bringing adverse impact to the enterprise. Second, it is necessary to strengthen the effectiveness study of conveying subject of EIA results updating. Let three subjects: environmental protection departments, financial institutions and enterprises study who to update information which will be more timely and effective. This requires three parties to cooperate and timely build a database information system to timely convey the improvement results of enterprises which have been included in the EIA blacklist to the relevant parties ${ }^{19}$. The pace that private financial institutions and state-owned financial institutions participate in green credit is still inconsistent ${ }^{20}$. State-owned financial institutions improve the credit threshold of high energy consumption, heavy pollution and high profit enterprises from the perspective of environmental protection. But the nature of pursuing profit maximization often 
make private financial credit can't find control power for such investment and financing. On one hand, this makes high energy consumption and heavy pollution enterprises more easily access to credit capital, which makes it more difficult to urge high energy consumption and high pollution enterprises to strengthen environmental protection from the perspective of economic transformation and the new and old kinetic energy conversion; on the other hand, this also increases the risk of private financial capital, which is not conducive to the macroeconomic regulation and control of national economic development.

\section{Policy recommendations to improving the green credit incentive mechanism}

To improve the green credit incentive mechanism, the key is to strengthen the bank's risk management, and the bank improves the environmental awareness of enterprises through credit means. At the same time, the bank reduces its own business credit risk by focusing on enterprises' environmental risks. As the loan business is mainly concentrated in the "three high" industries such as steel and cement, the implementation of green credit has reduced the credit risk to a certain extent, but this is a great test of the profitability of commercial banks. Based on this, to achieve the sustainability of green credit, we need to focus on the following aspects.

\subsection{The enterprise-bank game should introduce regulatory constraints}

According to the theory of game theory, if the external conditions are limited, the Pareto optimal choice based on the maximization of individual interests often leads to the "conspiracy" between the bank and enterprise. Therefore, it is necessary to introduce the third party supervisory department or the government intervention to realize dominant equilibrium strategy of both parties. To this end, on the one hand, the government needs to strengthen the supervision of the banking sector and enterprises. Strengthen supervision and enforcement efforts of environmental protection departments to enterprises, and the supervision of the People's Bank and China Banking Regulatory Commission on banks. The three parties build national regulatory system with clear responsibility. On the other hand, non-governmental regulation can reduce the supervision expenditure and expenses. Various forms of environmental groups, news media and general public, corporate employees conduct all-round social and public opinion supervision before and after the event on both parties of game. This will be the most powerful auxiliary force of government supervision. 


\subsection{Build green credit tripartite interests coordination mechanism}

Due to the fact that the implementation of green credit failed to achieve the interest maximization of government, banks and enterprise stakeholders, in order to mitigate the conflicts of interest loss, improve the green credit interests coordination mechanism which mainly focuses on solving the interest loss and benefit-sharing compensation and incentives, so as to protect the tripartite coordination interests to achieve the best ${ }^{21}$. From the perspective of government, the central or provincial governments increase the financial investment in "green industry" construction, improve the performance evaluation proportion of "environmental improvement", let government lead led the fund-raising and construction of "green fund", provide green loan projects or enterprises with technical support, interest compensation, stimulate the operation of green credit products and innovative financial institutions with good development ${ }^{22}$. Give price compensation to consumers who purchase green products, prompt the government to achieve the sustainable development of green industry by taking "performance preferences" as the driving force. On enterprise level, attract "green talent", and gradually introduce low-pollution machinery and equipment, control enterprise green credit risk.

\subsection{Use legal and fiscal means to boost the development of green credit and strengthen the social responsibility of green credit subjects}

Legal and taxation have always been the main constraint to solve environmental problems, green credit development is also inseparable from the legal and tax means. At present, the law on green credit is still in a guiding position; poor legal operability leads to low illegal costs. Join the green credit to "Commercial Bank Law", and confirm the obligations and responsibilities of both sides of green credit in legal form. In order to protect the interests of commercial banks, green credit needs to strictly prohibit private capital and other forms of funds from helping pollution enterprise in law, and promote environmental liability insurance $^{23}$. Exempt from part of the tax for investors who purchase financial products such as green funds, reduce or remit the tax of green enterprises, deduct taxes and dues when purchasing low-pollution equipment, and collect sewage charge from high-pollution enterprises. According to the amount of green loans, reduce or remit part of the bank tax, give full play to leverage role of finance and taxation to promote the enthusiasm of bank enterprises. Emphasize the social responsibility of commercial banks and enterprises to save energy and reduce emission, improve the green credit accountability system, strengthen the 
responsibility of commercial banks to strictly control the loan of high-energy projects, prohibit making loans to non-environmental projects restricted or eliminated by the country, and regular disclose the information of green credit implementation.

\subsection{Establish commercial bank environmental assessment intelligence support platform}

Commercial banks green credit is carried out late. It not only urgently needs various policy and technical analysis personnel, but also needs to strictly control the risk control personnel in green credit risk management. Commercial banks gradually increase the focus and awareness on green credit from inside, set up green credit policy committee and green credit commissioner positions, guiding the strategic layout of the management to tend to environmental protection enterprises. Green Credit Committee is mainly responsible for green credit policy research and authorization approval, the Committee mainly includes all kinds of macroeconomic policies and technical analysis talents, and is the decision-making center of green credit. The construction of commercial bank environmental assessment intelligence support platform should establish a green credit think tank by combining the introduction of external talents and internal training. Policy and technical analysis talents can be employed from outside, strengthen the close contact with macroeconomic policy experts and environmental experts, and timely follow up the latest study ${ }^{24}$. The internal training of commercial banks involves a wide range. First is to strengthen the economic and environmental protection awareness training of the management, enhance the management's recognition in national development strategy and environmental protection awareness. Second is the professional knowledge training of green credit risk control staff, let them understand the industry development direction, industry competition and potential risks, especially the financial needs and profit margins of high-polluting industries in China at different stages of development, closely connect enterprises with the environmental risks of bank development.

\subsection{Establish green credit environment data sharing information base to reduce the cost redundancy caused by information asymmetry}

Because of the poor information sharing among enterprises, commercial banks, environmental protection departments and CBRC, the asymmetry of environmental information causes the risk control costs and potential risks of financial institutions to further increase and can't realize the sustainable development of green credit. Take the bank as the main body, establish multiple information sharing system including tracking the adjustment of national industrial 
policy, contacting the national environmental protection departments, tracking the investment, production and construction of enterprises' environmental protection projects. Include the enterprise environmental information into enterprise credit information database to understand the potential risks of enterprise and control its credit risk. Encourage enterprises to establish product information system covering the whole process of production and sales and pollutant discharge, share the green product information with the banking industry, and reduce the information cost of communication between banks and enterprises.

We believe that the solution to China's environmental protection and governance issues can't be entirely dependent on government intervention; neither can it rely entirely on economic angle. It should use these two ways in combination. This paper conducts studies from the perspectives of credit support in China's environmental protection, policy intervention, information communication mechanism and environmental propaganda. It identifies the main responsibilities and obligations of various parties; it emphasizes the multi-sectoral and multiagent communication and cooperation, and requires financial institutions to strengthen the propaganda of green credit, conduct scientific classification and speed up innovation, and be targeted to do financial services work related to environmental protection well; aim to provide feasible and objective research results for decision-makers and substantive departments as a basis for decision-making and implementation, providing a reference for China's environmental protection and environmental management.

\section{Conclusions and deficiency}

Based on the domestic and international research results, this paper fully combines the existing credit policy of China's financial institutions, and analyzes the challenges faced by China's green credit policy from many sides: first, the status and responsibility are not clear in the tripartite cooperation; second, standards are not unified and have poor channel to publish authoritative and impartial EIA report to society in time; third, the information platform construction is not effective, and EIA results updating is not in time; fourth, the pace that private financial institutions and state-owned financial institutions participate in green credit is not consistent. In order to realize the sustainable development of green credit business, this paper constructs five green credit incentive systems from the aspects of system innovation and product innovation: first, the game between bank and enterprises must introduce supervision and control; second, construct green credit tripartite interests coordination system; third, use legal and fiscal means to boost the development of green credit and strengthen the 
social responsibility of green credit subjects; fourth, establish commercial bank environmental assessment intelligence support platform; fifth, establish green credit environment data sharing database, and reduce cost redundancy due to information asymmetry.

The deficiency of this paper is mainly that it has not yet conducted deep analysis of the interests, social responsibility and cooperation of state-owned and private financial institutions from the perspective of linkage sharing. This is subject to the future follow-up research. On the basis of deeply analyzing and identifying responsibilities and status of various subjects, systematically build the path and policy recommendations of green finance sustainable development from the level of ecological civilization construction and conversion of old and new kinetic energy.

\section{Acknowledgment}

This work was financially supported by Post funded project of National Social Science Foundation "The modern theory and policy research of environmental economics in China“(11FJY007).and Shandong science and technology development plan project "Study on the environmental law enforcement system in Shandong Province” (2014GGH222001).

\section{References}

1. M. Aizawa, C. F. Yang, Green credit,green stimulus, green revolution? China's mobilization of banks for environmental cleanup.The Journal of Environment \& Development[J].2010,19(2):119-144.

2. B. Zhang, Y. Yang, J. Bi. Tracking the implementation of green credit policy in China:Top-down perspective and bottom-up reform[J].Journal of environmental management, 2011,92(4):1321-1327.

3. J. M. Conley, C. Williams, Global banks as global sustainability regulators [J].Law\&Policy,2011,33(4) :542-575.

4. S. Thomas, R. Repettp, Integrated environmental and financial performance melrics for investment analysis and portfolio management[J].The Authors Journal Compilation,2007,15 (3) :421-426

5. J. Elizelle, Sustainable green urban planning:the workbench spatial quality method[J].The Journal of Place Management and Developnlent,2011 .4 (2) :214-224.

6. C. Zheng, Some Thinking on Green Credit Construction of China's Banking [J]. Zhejiang Finance, 2013, (1): 9-11.(In Chinese) 
7. N. W. Hu, D. W. Cao, Green Credit and Environmental Commercial Banks Risk Management [J]. Economic Issues, 2011, (3): 103-107. (In Chinese)

8. H. J. Cao, H. M. Chen, Game Analysis on China's Green Credit Transaction Behavior in Uncertain Environment [J]. Finance Theory and Practice, 2010,(2):17-22. (In Chinese)

9. L. Y. Zhang. Low Carbon Credit - China's Commercial Banks Green Credit Innovation Research [J]. Finance Review, 2010, (4): 34-37. (In Chinese)

10. L. M. Chen, L. H. Guo, W. W. Zhang, The Operation Mechanism and Implementation Path of China's Green Credit Policy [J]. Contemporary Economic Research, 2016,(1):91-96. (In Chinese)

11. X. L. Jiang, H. L. Xu. Study on the Operation Mechanism of Green Credit of Chinese Commercial Banks [J]. China Population Resources and Environment, 2016, (5): 490492. (In Chinese)

12. Y. Zeng, D. Chen, Institutional Innovation of Green Credit in the Background of Supply Side Reform [J] .Jiangxi Social Sciences, 2016, (4): 48-52. (In Chinese)

13. H. L. Cai. China's Green Credit Policy Implementation Status and its Effect Test Based on The Empirical Evidence of Paper, Mining and Power Industry[J]. Collected Essays on Finance and Economics, 2013, (1): 69-75. (In Chinese)

14. J. Y. Liu, Y. Xia, S. M. Lin, J. Wu, Y. Fan. Study on Short, Medium and Long Term Impact of China 's Green Credit Policy Based on Financial CGE Model [J]. China Management Science, 2015, (4): 46-52. (In Chinese)

15. Z. Y. Hu, C. Chen, W. Zhang. Study on Green Credit and Water Pollution Control Feedback Strategy Based on Differential Game [J]. Audit and Economy Research, 2013, (6): 100-109. (In Chinese)

16. J. N. Wang, C. Z. Ge, J. T. Yang, "Environmental Investment and Financing Strategy", China Environmental Science Press, 2003. (In Chinese)

17. China Environmental Protection Administration Environmental Planning Institute: "Investment and Financing Mechanism of Innovative Environmental Protection", China Environmental Science Press, 2004. (In Chinese)

18. M. H. Shen: "Study on Environmental Economic Means", China Environmental Science Press, 2001. (In Chinese)

19. Y. Luo, X. F. Zeng, "Economic Means of Environmental Protection", Peking University Press, 2001. (In Chinese) 
20. "Green Credit Policy and Practice Symposium Proceedings", State Environmental Protection Administration Environmental and Economic Policy Research Center, 2007.10. (In Chinese)

21. X. L Cheng, H. Y. Song, Reflection on China's Current Environmental Protection Investment and Financing Situation, Yunnan Geographical Research, 2006.01, 83-86. (In Chinese)

22. S. M Zou, J. N. Wang, Y. X. Hong, et al. "National "Eleventh Five-Year" Environmental Protection Planning Research Report", China Environmental Press, 2006.05. (In Chinese)

23. H. Q. Jiang, The Mechanism and Contribution Model of Environmental Protection Investment's Role on Economy, Systems Engineering Theory and Practice, 2004.12,818. (In Chinese)

24. Z. H. Chen, Environmental Investment and Financing: Theory, Problems and Countermeasures, Wuhan University of Science and Technology, 2006.09,38-41.(In Chinese) 